\title{
Synovial chondromatosis of the hand: Three case reports and literature review
}

\author{
Sarah Hew-Ming Wong BSC ${ }^{1}$, Sam Salama MD FRCPC ${ }^{2}$, Achilleas Thoma MD FRCSC ${ }^{3}$
}

SH -M Wong, S Salama, A T homa. Synovial chondromatosis of the hand: Three case reports and literature review. $C$ an J Plast Surg 2003;11(1):47-52.

Synovial chondromatosis is a rare condition that is probably caused by synovial connective tissue metaplasia. It is very rare in the hand and wrist and because of its low prevalence and nonspecific symptoms, synovial chondromatosis can present diagnostic difficulties for the hand surgeon and may lead to a delay in treatment. We review the literature and report three additional cases of synovial chondromatosis in the hand.

Key W ords: $\mathrm{H}$ and; $\mathrm{O}$ steochondromatosis; Synovial chondromatosis

\section{L a chondromatose synoviale de la main : Trois rapports de cas et une analyse bibliographique}

\begin{abstract}
La chondromatose synoviale est une maladie rare probablement causée par une métaplasie des tissus conjonctifs synoviaux. Elle est très rare dans la main et sur le poignet et, en raison de sa faible prévalence et de ses symptômes non spécifiques, elle peut présenter des problèmes diagnostiques pour le chirurgien de la main et entraîner un report du traitement. $\mathrm{N}$ ous avons analysé la documentation scientifique et présentons trois autres cas de chondromatose synoviale de la main.
\end{abstract}

Synovial chondromatosis is a rare condition in which multi$S$ ple cartilaginous nodules develop in the synovial membrane of joints, bursae or tendon sheaths as a result of subsynovial connective tissue metaplasia (1). A lthough this condition usually involves large joints such as the knee, it has in very rare instances been reported in the hand and wrist. Because of its low prevalence and nonspecific symptoms, synovial chondromatosis can present diagnostic difficulties for the hand surgeon and may lead to a delay in treatment. We review the literature and report three additional cases of synovial chondromatosis in the hand encountered in the practice of the senior author (AT).

\section{C ase 1}

\section{CASE PRESENTATION S}

A 66-year-old woman who was seen in 1997 complained of increasing swelling on the dorsum of the right index finger of two years' evolution. The swelling had become increasingly painful over the previous two months, restricting the range of motion and daily activities. There was no history of trauma or overuse. Examination revealed a soft mass over the ulnar aspect of the proximal interphalangeal (PIP) joint of the right index finger, with no involvement of the skin. Radiographs of the index finger showed soft tissue swelling with some indentation on the dorsum of the proximal phalanx. Surgical excision revealed a $1.2 \times 0.4 \mathrm{~cm}$ area of firm, whitish, cartilaginous tissue. $\mathrm{H}$ istological examination demonstrated mature hyaline cartilage surrounded by fibrous tissue and partly lined by synovium, which was consistent with synovial chondromatosis (Figure 1).
Two years later, the lesion recurred in the same location, with dull aching pain. Examination revealed a small, firm, mobile cyst on the radial aspect of the PIP joint extending along the radial, dorsal and volar sides of the joint. Radiographs showed two bony defects on the proximal aspect of the middle phalanx and the distal aspect of the proximal phalanx. Surgical re-excision revealed white mucoid and nodular soft tissue. Pathological examination once again demonstrated nodular cartilaginous tissue consistent with synovial chondromatosis.

Three years later, the nodules recurred a second time on the right index finger (Figure 2), with scalloping of the neck of the proximal phalanx (Figure 3). Multiple round lesions were removed from the joint space (Figure 4). No recurrence was observed after one year of follow-up.

\section{C ase 2}

A 44-year-old man presented in 1986 with a swelling over the right third metacarpal bone near the metacarpophalangeal (M CP) joint. There was no history of pain or trauma. The mass had gradually increased in size without affecting range of motion. A bone scan showed increased activity over the joint.

A dorsal incision was made, revealing a large encapsulated soft tissue tumour under the extensor tendon measuring $2 \mathrm{~cm}$ in diameter. This extended across the joint into the proximal phalanx. The capsule contained multiple fragments of cartilaginous material. Pathology revealed hyaline cartilaginous tissue lined by synovium, which was consistent with synovial

${ }^{1}$ Faculty of M edicine, U niversity of C algary, C algary, A lberta; ${ }^{2}$ D epartment of Pathology, ${ }^{3}$ D epartment of Surgery, Division of Plastic Surgery, St Joseph's $\mathrm{H}$ ealthcare and M cM aster U niversity, $\mathrm{H}$ amilton, $\mathrm{O}$ ntario

Correspondence: Dr A chilleas T homa, 206 James Street South, Suite 101, H amilton, O ntario L 8P 3A 9. Telephone 905-523-0019,

fax 905-523-0229, e-mail athoma@mcmaster.ca 


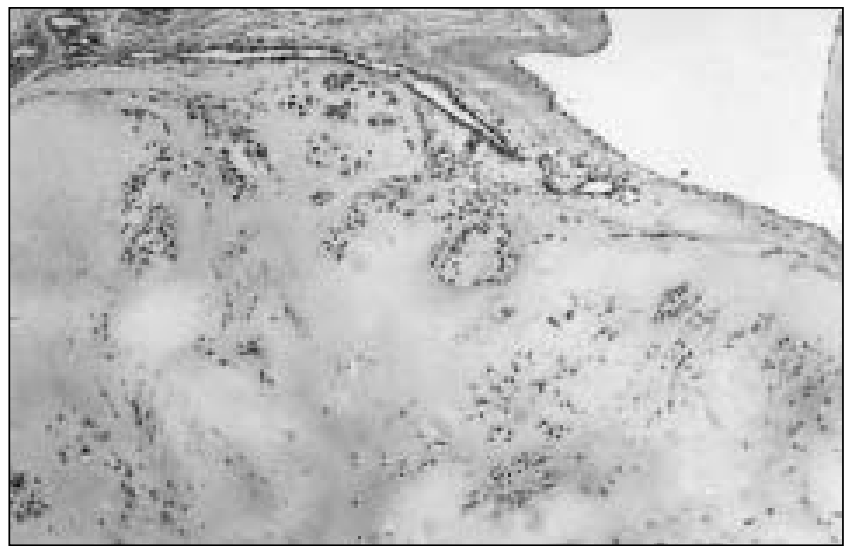

Figure 1) Case 1. H istopathology of the mass on the dorsum of the proximal phalanx. N otice the mature hyaline cartilage surrounded by fibrous tissue and partly lined bysynovium (hematoxylin and eosin stain, original magnification $\times 50$ )

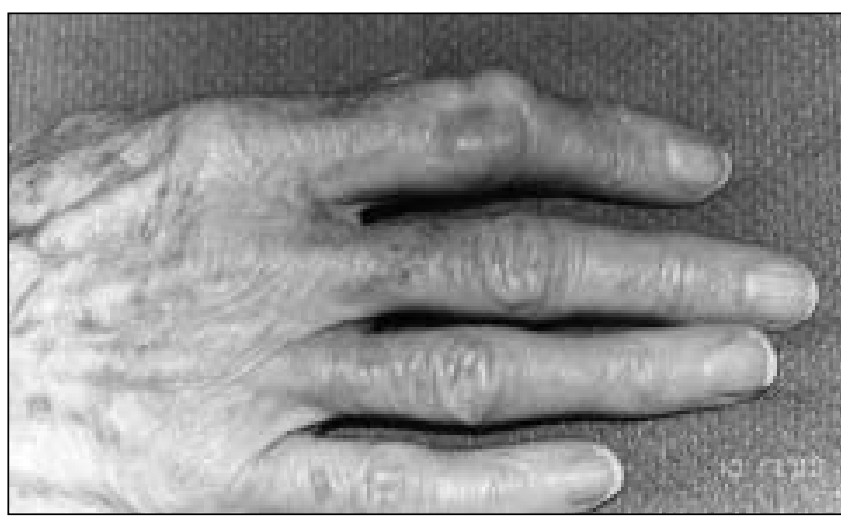

Figure 2) Recurrent synovial chondromatosis on the dorsum of the proximal interphalangeal joint of the right index finger

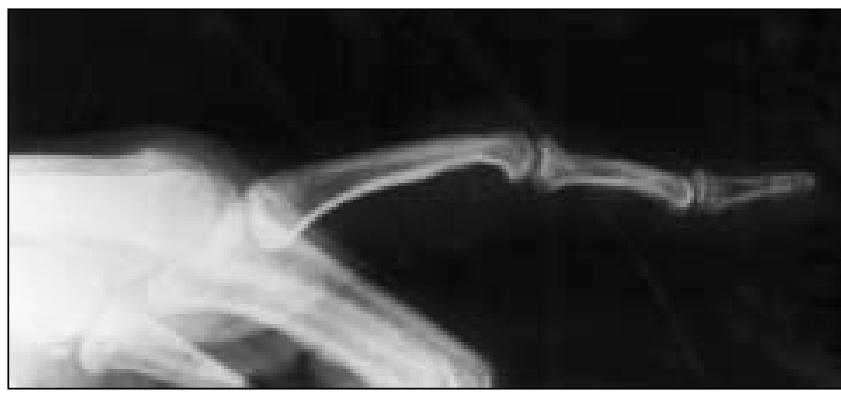

Figure 3) Scalloping of the volar cortex of the neck of the proximal phalanx due to synovial chondromatosis

chondromatosis. Surgical excision of the remaining synovium through a volar approach was carried out.

Six years later, the tumour recurred over the right third M C P joint. Radiographs demonstrated extraosseous cal cifications (Figure 5) and the bone scan revealed increased uptake over the same area. Surgical excision yielded hard pearly nodules (Figure 6). H istology demonstrated mature hyaline cartilage with varying degrees of ossification, which was consistent with synovial chondromatosis (Figure 7).

Two years later, the lesion recurred and was surgically resected. A II fragments of extraosseous and synovial enchon-

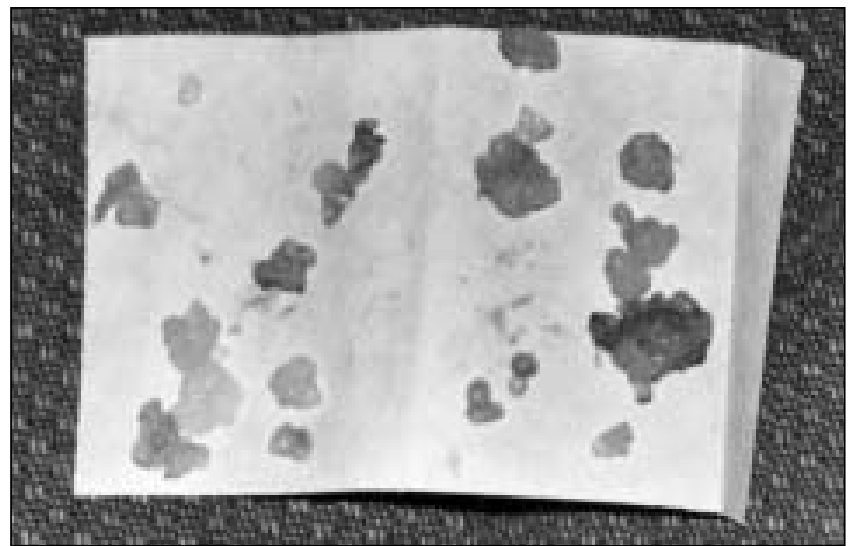

Figure 4) Excised fragments of synovial chondromatosis

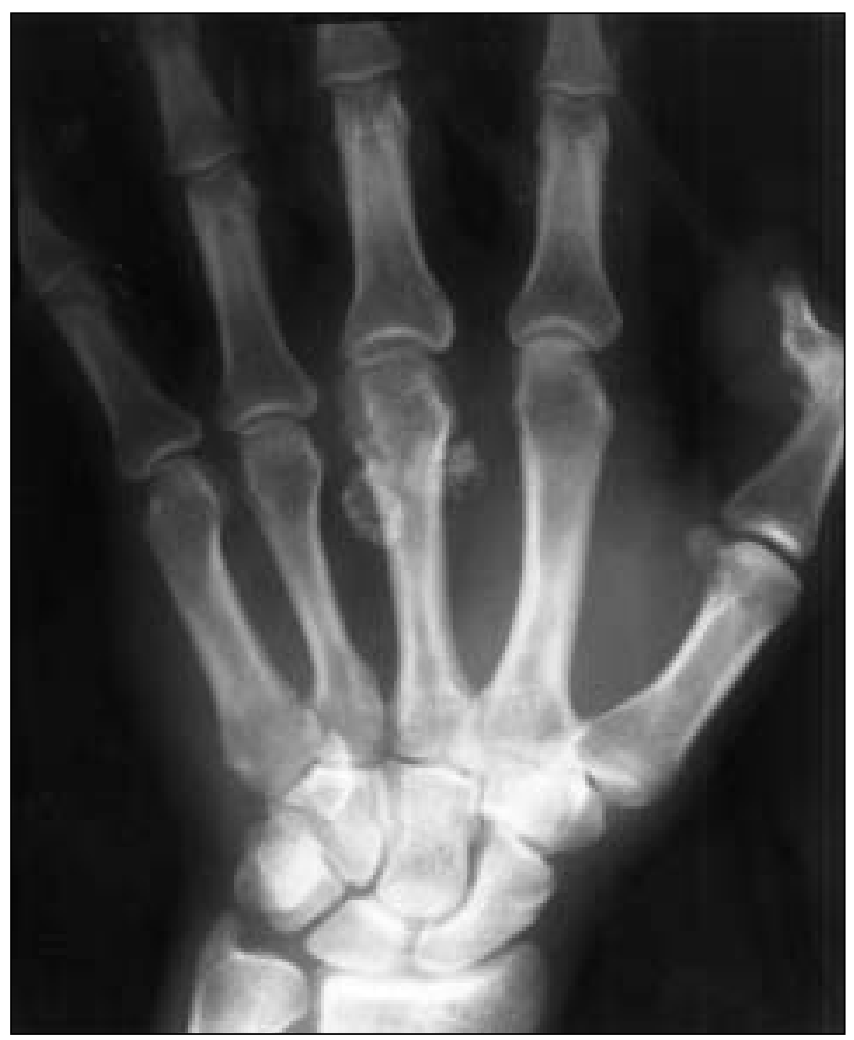

Figure 5) Extraosseous ossifications seen at the neck of the third metacarpal ( synovial chondromatosis)

dromatosis tissue were removed in addition to a capsule of synovial tissue. There was no recurrence for the subsequent two years of follow-up.

\section{C ase 3}

A 34-year-old woman presented with complaints of pain and swelling over her right index finger. There was no history of injury and the swelling had been gradually increasing in size over the previous eight years. The swelling was located primarily over her PIP joint, with some limitation in range of motion. Radiographs demonstrated a large soft tissue mass with 


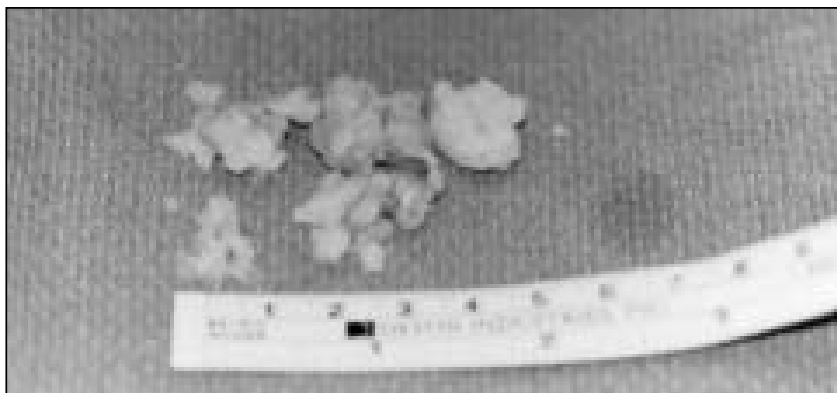

Figure 6) Excised synovial chondromatosis

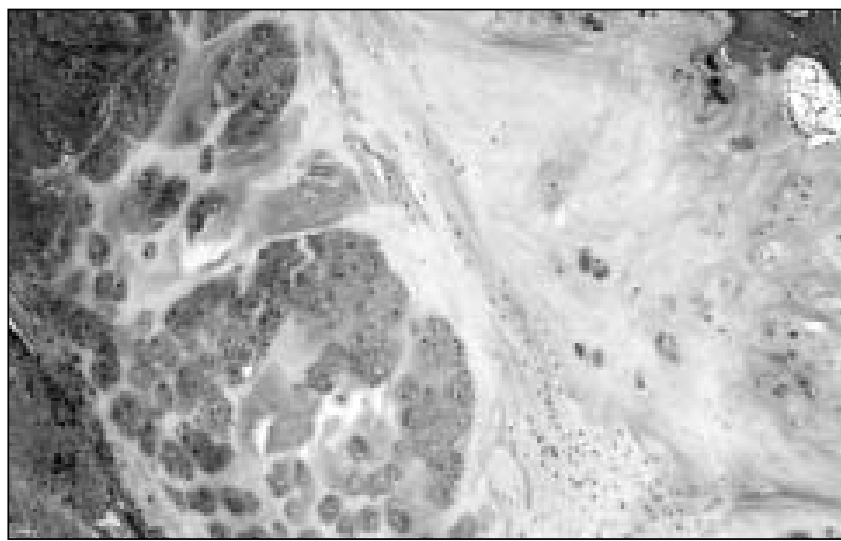

Figure 7) Case 2. H istopathology of the mass over the right third metacarpal bone near the metacarpophalangeal joint. $\mathrm{N}$ otice the nodules of hyaline cartilage showing focal ossification with calcification ( hematoxylin and eosin stain, original magnification $\times 50$ )

small calcifications over the ulnar aspect of a normal PIP joint (Figure 8).

A mid-lateral incision was made. The tumour was excised down to the periosteum (Figure 9). Parts of the collateral ligament were also involved and were removed. Pathology revealed fibrous tissue containing cartilaginous areas with foci of bone with calcification (Figure 10).

Ten years after the excision there was no recurrence.

\section{LITERAT U RE SEARCH}

A literature search for publications discussing synovial chondromatosis of the hand or wrist was conducted through PubM ed using the following search strategy: (synovial chondromatosis OR synovial osteochondromatosis OR chondromatosis OR osteochondromatosis) AND (hand OR wrist OR finger $O R$ metacarpophalangeal $O R$ interphalangeal $O R$ phalan* OR carpophalangeal OR carpal OR radiocarpal OR radioulnar). A bstracts and articles in English were included. References of relevant papers were reviewed. A separate search was also conducted for general articles on the disease.

The literature search yielded 167 publications, seven of which did not have an English abstract. Fifty-seven relevant articles were identified from the remaining 160 abstracts. A fter reviewing their reference lists, a total of 96 papers discussing synovial chondromatosis in the hand from the years 1902 to 2000 were identified. A II were case reports, which limited the

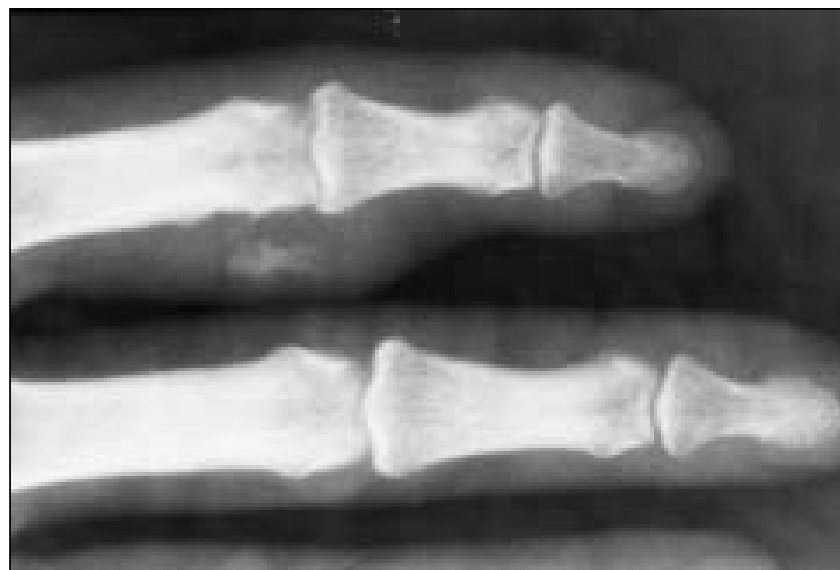

Figure 8) Extraosseous calcification on the ulnar side of the proximal interphalangeal joint of the index finger

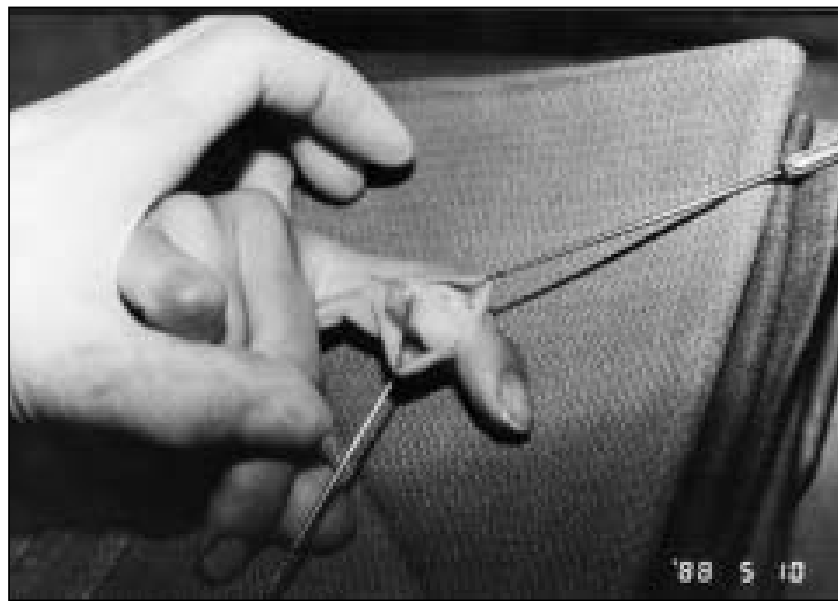

Figure 9) Intraoperative view of synovial chondromatosis

quality of evidence available from which to draw definite conclusions.

\section{DISC U SSION}

Synovial chondromatosis refers to the development of cartilage from synovial connective tissue in which secondary calcification and ossification commonly occur. Multiple loose bodies are seen when cartilaginous foci become pedunculated and detached. $C$ ases affecting the hand and wrist are rare, with one retrospective case series reporting a prevalence of $7.5 \%$ among 53 synovial chondromatosis cases (2) compared with $74 \%$ in the knee. O ne hundred two cases of synovial chondromatosis of the hand were found in the literature (Table 1 ).

\section{Clinical presentation}

The clinical diagnosis of synovial chondromatosis can be difficult because of its low incidence and nonspecific symptoms. The greatest number of hand lesions appear to be located in the finger and more frequently involve the flexor surfaces (3). Primary synovial chondromatosis in the hand and wrist occurs most commonly from the ages of 30 to 60 years, with both sexes being affected equally. The dominant hand seems to be 


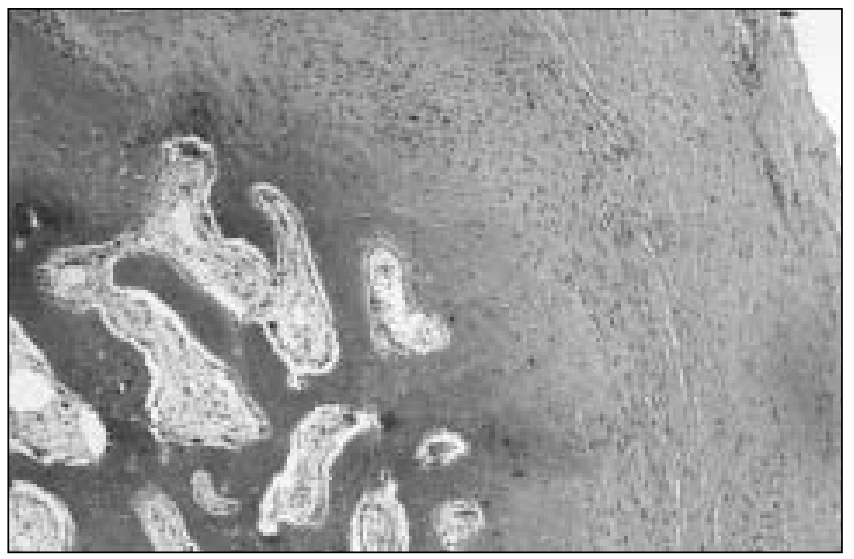

Figure 10) Case 3. $\mathrm{H}$ istopathology of the mass overlying the right index finger. $\mathrm{N}$ otice the fibrous tissue containing cartilage showing foci of bone with calcification (hematoxylin and eosin stain, original magnification $\times 5$ )

involved preferentially (3). The majority of patients report no significant trauma to the affected area, and clinical evidence of infection or other inflammatory reactions of the synovium is usually lacking. Patients may present with pain, swelling, stiffness and/or limitation of motion in the affected joint due to the presence of loose bodies and an active synovium. These symptoms were demonstrated in our three cases. Examination of the joint may reveal tenderness, crepitus, effusion and palpable nodules, as well as a limited range of motion or locking. 0 ther associated symptoms that have been reported include stenosing tenosynovitis from an osteochondroma of the tendon $(4,5)$ and extreme pain due to a loose body over an extensor tendon (6).

The differential diagnosis includes rheumatoid arthritis, chronic infection (including tuberculosis), trauma (osteochondral fracture), osteochondritis dissecans, osteoarthritis, neuropathic arthritis and gout (7).

It is also important to differentiate the features of synovial chondromatosis from a chondrosarcoma. Clinically, the malignant lesion has a faster growth rate and is more invasive, causing more pain and swelling as it enlarges. $\mathrm{H}$ istologically, the malignant tumour can be differentiated by the loss of a solid matrix. Other features consistent with chondrosarcoma include bone destruction, diffuse hypercellularity with more significant nuclear hyperchromasia, and spindling of tumour cells at the periphery of the lobules (8). These were absent in all three cases presented.

\section{Investigations}

Roentgenographic changes are usually nonspecific, including the presence of a soft tissue mass, scattered calcifications or a radiopaque tumour, depending on calcification or ossification of cartilaginous nodules in the lesion (9). There have also been reports of new bone formation. This feature was demonstrated in two of our cases. A II three had osteophyte formation, which may have been related to the tumour. A Ithough the metaplastic changes of the synovium are self-limited, damage to the joint from multiple loose bodies may lead to early degenerative
TABLE 1

Published cases of synovial chondromatosis in the hand

\begin{tabular}{lcl}
\hline Site & $\begin{array}{c}\text { Reported } \\
\text { cases }(\mathbf{n})\end{array}$ & Reference \\
\hline Finger & & \\
$\quad$ Interphalangeal joint & 12 & $3,6,7,26-32$ \\
$\quad$ Flexor tendon & 27 & $3-5,18,33-43$ \\
$\quad$ Extensor tendon & 13 & $3,12,35,36,43-48$ \\
$\quad$ Other or unspecified & 3 & $10,27,49$ \\
Metacarpophalangeal joint & 14 & $3,5,10,43,49-55$ \\
Palm & 5 & $1,35,49,56,57$ \\
Wrist & 28 & $3,8,13,16,27,28,33,35$, \\
& & $45,46,48,57-68$ \\
\hline
\end{tabular}

arthritis. There have also been reports of diagnostic imaging studies using ultrasound, computed tomography and magnetic resonance imaging (9).

\section{Pathology}

The histopathological analyses of the three cases reported in the present article demonstrate the common features of synovial chondromatosis. On gross pathological examination, synovium can be affected focally or diffusely, with multiple nodules of varying sizes concentrated near the synovialcartilaginous junction. O ccasionally, a giant solitary cartilaginous nodule is seen (10). In all of our three cases, numerous cartilaginous nodules were present intraoperatively with small foci of calcification. Microscopic examination demonstrates focal, circumscribed areas of hyaline cartilage embedded within synovial connective tissue. Certain authors require intrasynovial involvement to be present before making a diagnosis of synovial chondromatosis $(6,11)$. This feature was present in two of our three cases. Some nodules also contain bony trabeculae and mature osteoid with bone marrow elements (termed osteochondromatosis). Cytological features include enlarged chondrocytes, hypercellularity and pleomorphic nuclei. Despite these features of aggressive growth, the natural history of the disease is one of slow and usually self-limiting progression. Milgram (8) classified the disease process into three phases: early, with active intrasynovial disease but no loose bodies; transitional, with active disease and loose bodies; and late, with multiple loose bodies but no intrasynovial disease.

A lthough the exact pathogenesis of the condition is unknown, it has been postulated that multipotential synovioblasts undergo multifocal metaplasia to form chondroblasts, leading to the formation of cartilaginous nodules. C ells resembling fibroblasts are arranged to form a primitive chondroid matrix, which supports the growth of nodular cartilage. This is either by proliferation of interstitial cells or by surface growth of new cells differentiating near the surface to form a matrix.

\section{$M$ anagement}

It has been repeatedly observed that pain and other symptoms are relieved by the evacuation of the loose bodies, and complete excision of the lesion is commonly accepted. However, 
further surgical treatment in terms of synovectomy to prevent recurrence has been controversial. Some authors $(12,13)$ advocate the removal of loose bodies with synovectomy, while others recommend the removal of loose bodies alone (14). Two of our cases demonstrated recurrences twice each, with or without synovectomy. The lone published case series specifically involving the hand demonstrated a recurrence rate of $24 \%$ (five of 21 cases), even with synovectomy (3). A retrospective study of 13 patients with synovial chondromatosis of the knee observed a lower rate of recurrence after complete synovectomy (zero of eight with synovectomy versus three of five without) (15). This has not been confirmed in other retrospective studies (2). Because of equivocal recurrence with or without synovectomy, Maurice et al (2) recommended synovectomy only for symptomatic relief from pain and swelling, and the removal of loose bodies for mechanical symptoms. Larger controlled studies are needed to determine the most appropriate treatment, but, unfortunately, the low incidence of disease precludes randomized trials.

\section{REFEREN CES}

1. Sim FH, Dahlin DC, Ivins JC. Extra-articular synovial chondromatosis. J Bone Joint Surg A m 1977;59:492-5.

2. Maurice $H, C$ rone $M$, W att I. Synovial chondromatosis. Bone Joint Surg A m 1988;70:807-11.

3. Roulot $E$, Le Viet. Primary synovial osteochondromatosis of the hand and wrist. Report of a series of 21 cases and literature review. Rev Rhum Engl Ed 1999;22:1093-7.

4. Rockey HC. Trigger-finger due to a tenosynovial osteochondroma. J Bone Joint Surg A m 1963;45:387-8.

5. Cremone JC, W olff TW, W olfort FG. Synovial chondromatosis of the hand. Plast Reconstr Surg 1982;69:871-4.

6. Lewis M M, M arshall JL, M irra JM. Synovial chondromatosis of the thumb. J Bone Joint Surg A m 1974;56:180-3.

7. Kumar A, Thomas A P. Swelling of a metacarpophalangeal joint. Postgrad M ed I 2000:76:430-1.

8. M ilgram JW. Synovial osteochondromatosis: A histopathological study of thirty cases. J Bone Joint Surg A m 1977;59:792-801.

9. Crotty JM, M onu J, Pope T. Synovial osteochondromatosis. Radiol Clin N orth A m 1996;34:327-42.

10. C onstant $\mathrm{E}, \mathrm{H}$ arebottle $\mathrm{NH}$. Synovial chondromatosis of the hand: Case report. Plast Reconstr Surg 1974;54:353-7.

11. A pte SS, A thanasou NA . A n immunohistological study of cartilage and synovium in primary synovial chondromatosis. J Pathol 1992;166:277-81.

12. Jaffe HL. Tumors and Tumurous $\mathrm{C}$ onditions of the Bones and Joints. London: Henry Kimpton, 1958.

13. M urphy FP, Dahlin DC, Sullivan CR. A rticular synovial chondromatosis. J Bone Joint Surg A m 1962;44:77-86.

14. Jeffreys TE. Synovial chondromatosis. J Bone Joint Surg Br 1967;49:530-4

15. O gilvie-H arris DJ, Saleh K. G eneralized synovial chondromatosis of the knee: A comparison of removal of the loose bodies alone with arthroscopic synovectomy. A rthoscopy 1994;10:66-70.

16. Jones JR, Evans DM, Kaushik A. Synovial chondromatosis presenting with peripheral nerve compression - a report of two cases. I H and Surg Br 1987;12:25-7.

17. Perry BE, M CQ ueen DA, Lin JJ. Synovial chondromatosis with malignant degeneration to chondrosarcoma. J Bone Joint Surg A m 1988:70:1259-61.

18. Henderson M S. Loose bodies in joints and bursae due to synovial osteochondromatosis. J Bone Joint Surg 1923;5:400-23.

19. Goldman RL, Lichtenstein L. Synovial chondrosarcoma. Cancer 1964:17:1233-40.

20. Benoit J, A rnaud E, M oulucou A, et al. O steochondromatose synoviale du genou et chondrosarcome synovial. Rev Chir O rthop 1990;6:198-203.

\section{Complications}

Complications of synovial chondromatosis include secondary degenerative osteoarthritis and mechanical locking, with limitation of function due to loose bodies in the joint space. N erve compression by the mass has also been reported (16). Controversy remains as to whether synovial chondromatosis undergoes malignant change to become a chondrosarcoma. W hile no such cases have been reported involving the hand or wrist, there have been several cases of chondrosarcomatous transformation in the knee (17-25).

\section{CONCLUSIONS}

Synovial chondromatosis of the hand is rare, usually presenting as a lesion with nonspecific clinical features. Surgical excision and histopathological examination are, thus, required for diagnosis. Management consists of complete excision and removal of loose bodies. Complete synovectomy is advocated; however, recurrence is still common. Further evidence is required to improve diagnosis and management.

21. C ase records of the $M$ assachusetts $G$ eneral $H$ ospital/C ase 23-1962 N England J Med 1962;266:725-9.

22. Hamilton A, Davis RI, N ixon JR. Synovial chondrosarcoma complicating synovial chondromatosis. J Bone Joint Surg A m 1987;69:1084-8

23. Hamilton A, Davis RI, Hayes D, M ollan RA. Chondrosarcoma developing in synovial chondromatosis. A case report. J Bone Joint Surg Br 1987,69:137-40.

24. Kenan S, A bdelwahab IF, Klein MJ, Lewis M M . C ase report 817. Skeletal Radiol 1993;22:623-6.

25. M ullins F, Berard CW, Einsenberg SH . Chondrosarcoma following synovial chondromatosis. Cancer 1965;18:1180-8.

26. Gil-A lbarova J, M orales-A ndaluz I, C astiella T, Seral F. Tenosynovial chondromatosis of the third finger. A rch 0 rthop Trauma Surg 2000;120:239-40.

27. Lichtenstein $\mathrm{L}, \mathrm{G}$ oldman RL. Cartilage tumors in soft tissues, particularly in the hand and foot. C ancer 1964;17:1203-8.

28. Kettelkamp DB, Dolan J. Synovial chondromatosis of an interphalangeal joint of a finger. J Bone Joint Surg A $m$ 1966:48:329-32.

29. Peh W C, Li JH, Gilula LA . A 28-year-old woman with swelling of the thumb. University of $\mathrm{H}$ ong Kong, Republic of China. A m J Orthop 1995:24:563-7.

30. Takami H, Takahashi S, A ndo M. Synovial chondromatosis of the proximal interphalangeal joint of a finger. J $\mathrm{H}$ and Surg A $\mathrm{m}$ 1994;19:794-6.

31. Kumar A, Thomas A P. Recurrent synovial chondromatosis of the index finger - $\mathrm{C}$ ase report and literature review. $\mathrm{H}$ and Surg 2000;5:181-3.

32. Harvey FJ, N egrine J. Synovial chondromatosis in the distal interphalangeal joint. J H and Surg A m 1990;15:102-5.

33. A egerter $E$, Kirkpatrick JA . O rthopedic Diseases, 5th edn. Philadel phia: W B Saunders C 0, 1975:685.

34. Strong M L. C hondromas of the tendon sheath of the hand. J Bone Joint Surg A m 1975;57:1164-5.

35. Murphy A F. Tenosynovial osteochondroma in the hand. J Bone Joint Surg A m 1958;40:1236-40.

36. DeBenedetti MJ, Schwinn CP. Tenosynovial chondromatosis in the hand. J Bone Joint Surg A m 1979;61:898-903.

37. Janik A. Tumours of tendon sheaths. A nn Surg 1927;85:897-911.

38. Shepard JA. O steochondroma of the tendon sheaths. A case arising from the flexor sheaths of the index finger. Br J Surg 1942;39:17-80.

39. G eschickter CF, Copeland M M. Tumors of Bone, 3rd edn. Philedel phia: JB Lippincott, 1949:689-99.

40. $N$ ather $A, C$ hong PY. A rare case of carpal tunnel syndrome due to tenosynovial osteochondromatosis. J H and Surg Br 1986;11:478-80. 
41. Buxton JD. Tumours of tendon and tendon sheaths. $\mathrm{Br} J$ Surg 1923:10:469-74.

42. Vinchon $B$, Polveche $G, C$ ordonnier $D$, Thery $D$, Butter $M$, de Ratier B. O steochondromatose teno-synoviale a la main. A propos d'une observation. A nn Chir Main 1991;10:343-7.

43. C atalano F, Fanfani F, Taccardo G. Lesions tumorales et pseudotumorales cartilagineuses des parties molles de la main. A $\mathrm{nn} \mathrm{C}$ hir Main 1988;7:314-21.

44. Patel MR, Desai SS. Tenosynovial osteochondromatosis of the extensor tendon of a digit: $C$ ase report and review of the literature. J $\mathrm{H}$ and Surg A m 1985;10:716-9.

45. Roberts P. Tenosynovial chondromatosis. A n unsual case. Br J Surg $1971 ; 58: 152$

46. Lynn M D, Lee J. Periarticular tenosynovial chondrometaplasia. J Bone Joint Surg A m 1972;54:650-2.

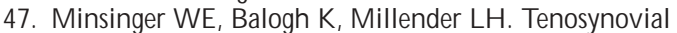
osteochondroma of the hand. Clin Orthop 1985;196:248-52.

48. Travers $V, A$ ugereau $B, A$ poil A . A propos d'un case de chondromatose tenosynoviale et d'un case d'osteochondromatose intra-articulaire de la main. Sem H op (Paris) 1983;59:1253-6.

49. Dahlin DC, Salvador A H. C artilaginous tumors of the soft tissue of the hands and feet. M ayo Clinic Proc 1974;49:721-5.

50. Reed SC, W right C S. Synovial chondromatosis of the metacarpophalangeal joint: $\mathrm{C}$ ase report and review of the literature. Can J Surg 1996;39:407-9.

51. Linden $\mathrm{O}$. C ase of chondromatosis of a metacarpophalangeal joint. A cta C hir Scand 1934;75:181-4.

52. Szepesi J. Synovial chondromatosis of the metacarpophalangeal joint. A cta O rthop Scand 1975;46:926-30.

53. M ylle J, van Delm I, Sciot R, van Damme B, De Smet L, Fabry G $C$ ondromatosis of the fifth metacarpophalangeal joint: $C$ ase report and review of the literature. A cta O rthop Belg 1992;58:346-8.

54. M uller W. U eber diffuses enchondrom der gelenkkapsel. A rch Fr Klin Chir 1902;LXVI:637-41.

55. Lucas G L, Sponsellar PD. Synovial chondrometaplasia of the hand:
Case report and review of the literature. J $\mathrm{H}$ and Surg A $\mathrm{m}$ 1984;9:269-72.

56. M CC arthy EF, Dorfman H P. Primary synovial chondromatosis - an ultrastructural study. Clin O rthop 1982;168:178-86.

57. Someren A, M erritt W H. Tenosynovial chondroma of the hand: A case report with a brief review of the literature. $\mathrm{H}$ um Pathol 1978;9:476-9.

58. Rompen JC, H am SJ, M olenaar W M, van H orn JR. Synovial chondromatosis of the wrist and hand - a case report. A cta O rthop Scand 1999;70:627-9.

59. Von Schroeder HP, A xelrod TS. Synovial osteochondromatosis of the distal radio-ulnar joint. J H and Surg Br 1996;21:30-2.

60. Taras JS, M eadows SE. Synovial chondromatosis in the radiocarpal joint. A m J O rthop 1995;24:159-60.

61. Ballet FL, Watson HK, Ryu J. Synovial chondromatosis of the distal radio-ulnar joint. J H and Surg A m 1984;9:590-2.

62. Lyritis G. Synovial chondromatosis of the inferior radio-ulnar joint. A cta O rthop Scand 1976;47:73-4.

63. Inada Y, Fukui A, M aeda M, Tamai S, Inada M. Reconstruction of the triangular fibrocartilage complex after surgery for treatment of synovial osteochondromatosis of the distal radio-ulnar joint. $\mathrm{J} H$ and Surg A m 1990;15:921-4.

64. O no H, Yajima, Fukui A, Tamai S. Locking wrist with synovial chondromatosis: Report of two cases. J H and Surg 1994:19:797-9.

65. Rogachefsky RA, Zlatkin M B, G reene TL. Synovial chondromatosis of the distal radioulnar joint: A care report. $\mathrm{J} H$ and Surg A m 1997;22:1093-7.

66. Kitazawa $\mathrm{H}$, I wasaki Y, U kai K, M izuno K, H irohata K. A case report of synovial chondromatosis of the wrist with multiple subsutaneous nodules. Rincho Seiki G eka 1986;21:159-64.

67. Bibergeil $\mathrm{E}$. Chondromatosis des $\mathrm{H}$ and-gelenkes. $\mathrm{Z} O$ rthop $\mathrm{C}$ hir 1913;33:620-9.

68. Riedel R. Kienbock. U ber G elenk-Kapselchondrose. Dtsch Z C hir 1917;62:232-44. 